\title{
Mechanisms of hypoxia frequency changes in the northern Adriatic Sea during the period 1972-2012
}

\author{
Tamara Djakovac ${ }^{\text {a }}$, Nastjenjka Supić ${ }^{\text {a }}$, Fabrizio Bernardi Aubry ${ }^{\mathrm{b}}$, Danilo Degobbis ${ }^{\mathrm{a}}$, Michele Giani ${ }^{\mathrm{c}, *}$ \\ a Center for Marine Research (CMR), Ruđer Bošković Institute, G. Paliaga 5, Rovinj 52210, Croatia \\ b Istituto di Scienze Marine, CNR - ISMAR, Venezia, Italy \\ c Istituto di Oceanografia e Geofisica Sperimentale (OGS), Via A. Piccard 54, 34151 Trieste, Italy
}

\section{A R T I C L E I N F O}

Article history:

Received 8 January 2014

Received in revised form 31 July 2014

Accepted 4 August 2014

Available online 11 August 2014

\section{Keywords:}

Hypoxia

Circulation patterns

Stratification

Long time series

Northern Adriatic Sea

\begin{abstract}
A B S T R A C T
Hypoxia events frequently occurred in the bottom layer of the northern Adriatic Sea (NAd) from mid-summer to mid-autumn, when the water column is highly stratified, with highly variable spatial extent and duration. To determine the mechanisms of changes in hypoxia frequency and their relation to environmental conditions, $40 \mathrm{yr}$-long time series of dissolved oxygen and of parameters that describe freshwater influence, stratification processes, and circulation patterns were analysed. It was shown that seasonal hypoxic events in the open water areas coincided with the formation of cyclonic or anticyclonic circulation cells, whose stability was estimated by the appearance of the Istrian Coastal Counter Current (ICCC). The oxygenation of bottom waters during the period August-November of the last two decades has increased, whereas a decreasing trend was observed in surface waters. The frequency of hypoxic events at a larger scale in the NAd decreased since 1992, concurrently with reduced ICCC occurrences. However, the frequency of events in the western area, which is under a direct influence of Po River discharges, did not change significantly, although their intensity recently were lower than during the 1970 s and 1980 s.
\end{abstract}

(C) 2014 Elsevier B.V. All rights reserved.

\section{Introduction}

Numerous coastal areas and estuaries over the world ocean are vulnerable to eutrophication. The consequences of this process, in the first place hypoxia or anoxia, can differ greatly among systems with similar external nutrient loads, being less severe in those with shorter flushing times and/or lower stability of the water column. Oxygen concentrations on continental margins are declining in many regions due to anthropogenic nutrient inputs (e.g. Diaz and Rosenberg, 2008; Rabalais et al., 2002). Increases in duration, intensity, and spatial extent of coastal hypoxia over the past several decades were attributed to growing urbanisation, land run-off of excess nutrients from fertilisers and atmospheric nitrogen depositions from fossil-fuel combustion. Moreover, warming is causing deoxygenation both in the world ocean (Keeling et al., 2010) and in the continental margin areas (Falkowski et al., 2011). Hypoxia in some coastal regions may be mainly related to climatic variations or trends (Doney, 2013).

The anthropogenic impact in the northern Adriatic (NAd) dates back to the Roman Empire (Lotze et al., 2006). However, the impact linked to increased nutrient load became more intense between the end of the XIX century and the beginning of the XX century (Barmawidjaja et al. 1995; Sangiorgi and Donders, 2004, and references therein). Hypoxic

\footnotetext{
* Corresponding author.

E-mail address: mgiani@inogs.it (M. Giani).
}

events in the NAd bottom waters were documented since the 1960s (Barmawidjaja et al., 1995; Degobbis et al., 2000; Justić et al., 1987; Rabalais et al., 2010 and references therein). Recently, this region was classified as a zone at medium to high risk of intermittent hypoxia and anoxia (UNEP, 2012), which leads to degradation of the benthic communities over large areas (Crema et al., 1991; Ott, 1992; Zuschin and Stachowitsch, 2009). The NAd has often been taken as a case study related to natural and anthropogenic hypoxia (Diaz, 2001; Gray et al., 2002; Rabalais et al., 2010; Steckbauer et al., 2011). Unfortunately, most of the available data were collected in limited areas of the NAd (western coastal belt: Rinaldi et al., 1992; Trieste gulf: Faganeli et al., 1985; Stachowitsch, 1984, 1991; Kollmann and Stachowitsch, 2001) which cannot be considered as representative of the entire NAd basin.

In this paper, an attempt was made to explain the mechanisms of observed changes in the frequency of hypoxia events in the NAd open waters based on oxygen data series collected in the period 19722012. To achieve this aim, temporal fluctuations of environmental conditions that were assumed to be the most relevant in the NAd were studied and compared with oxygen changes and trends. These conditions are: eutrophication pressure, due to freshwater nutrient discharges, traced by Po River flow rate values, changes in the circulation regime evaluated from geostrophic calculations, and stratification processes, described from vertical density differences in the water column. A hypothesis that global warming might also have influenced the oxygenation of the water column was also investigated. 


\section{Relevant characteristic of the study area}

The study area (Fig. 1) is located in the northernmost shallow part of the Adriatic Sea (NAd), north to the Rimini-Pula section (depth $<50 \mathrm{~m}$ ), which receives nutrient-rich freshwater from the Po River, one of the largest in the Mediterranean, and from several other smaller rivers and streams (Cozzi and Giani, 2011). The Po flow rate amounts to around $45 \mathrm{~km}^{3} \mathrm{yr}^{-1}$ (70\% of the total freshwater discharge in the region), with spring and autumn freshets up to $10,000 \mathrm{~m}^{3} \mathrm{~s}^{-1}$ (Cozzi and Giani, 2011). However, interannual variability in the seasonal cycle of Po flow rate is very high and can be characterised by absence of freshets in spring or, alternatively, in autumn or even during the entire year.

The stratification degree of the water column depends significantly on freshwater discharge in addition to surface fluxes (heat and water) across the air-sea interface. The sea gains heat from March to August (Supić and Orlić, 1999) and in that period stratification progressively increases. The circulation in the northern Adriatic is cyclonic, with the Eastern Adriatic Current (EAC) flowing along the eastern coast during the cold part of the year, whereas during the stratification period the geostrophic field is characterised by the formation of cyclonic and anticyclonic gyres (Krajcar, 2003), which can persist for several months (e.g. Orlić et al., 2013). Geostrophic currents seem to represent a realistic approximation of residual current fields in the NAd, where density differences in horizontal planes are very marked (e.g. Supić et al., 2012). As shown by previous studies, the geostrophic circulation can play an important role in the occurrence of hypoxic events during the stratification period (e.g. Supić et al., 2000). Gyres can advect freshened, nutrient-rich, waters, formed in the area off the Po River delta, over large parts of the NAd and even up to the opposite, eastern coast (Istrian peninsula; e.g. Degobbis et al., 2000). A significant fraction of the newly produced organic matter in these waters can settle over these areas, increasing the oxygen demand in the bottom layers, below the pycnocline. Typically, an anticyclonic gyre can form in the eastern part of the NAd by the end of winter and gradually intensify during spring and summer (Krajcar, 2003; Supić et al., 2000, 2003).

\section{Materials and methods}

\subsection{Sampling and measurements}

Water samples were collected using 5 L Niskin bottles at $0,5,10,20$, $30 \mathrm{~m}$, and $2 \mathrm{~m}$ above the bottom with an approximately monthly frequency at the stations of profile Rovinj-Po River delta (Fig. 1). Temperature was measured with protected reversing thermometers (Richter and Wiese, precision $\pm 0.01{ }^{\circ} \mathrm{C}$ and digital thermometers SIS RTM 4002, precision $\pm 0.003{ }^{\circ} \mathrm{C}$ ) assembled to the Niskin bottles. Salinity samples were analysed at the inland laboratory by high-precision salinometers (Beckman RS-7C and Yeo-Kal 601; precision of \pm 0.01 ), using algorithms recommended by UNESCO (1983). The dissolved oxygen (DO) was determined onboard by the Winkler method (Strickland and Parsons, 1972).

Furthermore, additional DO concentrations, temperature and salinity (used for the geostrophic current calculations) for the NAd areal

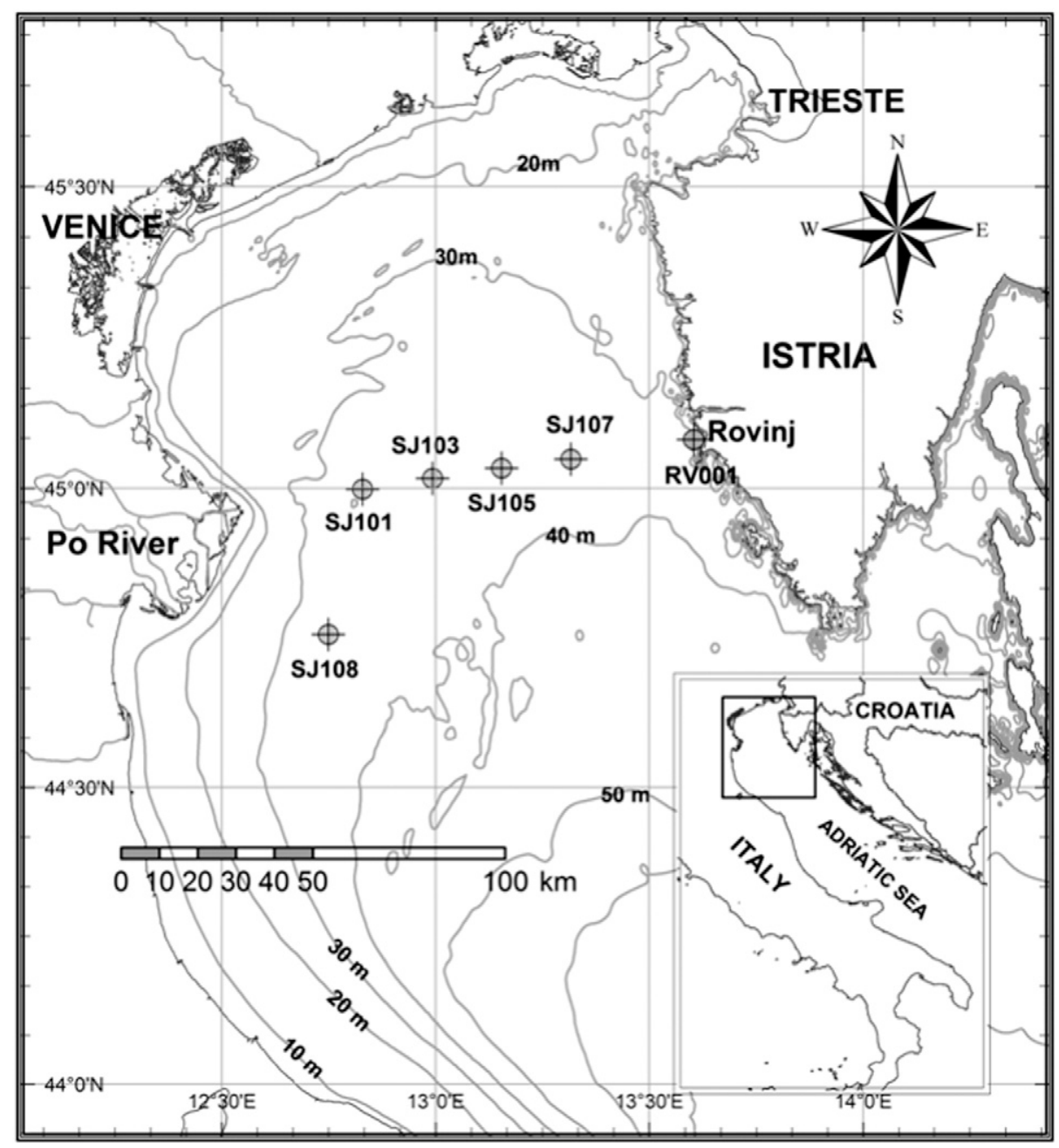

Fig. 1. The northern Adriatic Sea with sampling stations on the profile Rovinj-Po River delta. 
extension (> 15 stations) in years 1972, 1977, 1983 and 1989 were provided by the CMR Rovinj database, the OGS National Oceanographic Data Center (http://nodc.ogs.trieste.it/) and the Adriatic BioChemical Dataset (ABCD), version 4 (Zavatarelli et al., 1998).

The data for dissolved oxygen and dynamic heights in November 2003 and November 2006 were partly obtained from CTD measurements (Idronaut Ocean Seven 316 multiprobe) and also from water sampling at different depths $(0,1,5,15 \mathrm{~m}$, and near-bottom layer).

\subsection{Data elaboration and statistical analyses}

Temperature and salinity data collected at stations with depths of $30 \mathrm{~m}$ or more were used to compute dynamic depths of the $30 \mathrm{dbar}$ surface by means of a standard dynamic method (Supić et al., 2000). Distribution of dynamic depths, compared with bottom oxygen contents, for selected situations in the northern Adriatic was plotted only when data were collected quasi synoptically (3-4 days) or in a few cases within two weeks. Based on dynamic depths of the $30 \mathrm{dbar}$ surface, the geostrophic currents relative to $30 \mathrm{~m}$ depth were computed between each couple of neighbouring stations at the profile Rovinj delta Po (i.e., at SJ108/SJ101, SJ101/SJ103, SJ103/SJ105, SJ105/SJ107 and SJ107/RV001, Fig. 1; e.g. Supić et al., 2000). The currents are positive when they mark an inflow in the northern Adriatic and the ICCC is the current at SJ107/RV001 of negative sign.

As an index of stratification the difference between the density in bottom and surface layers was considered.

Descriptive statistical models were constructed for average seasonal and long-term cycles of temperature, density and dissolved oxygen (data from 1972 to 2002). The mean seasonal variation was obtained by a least squares regression of the data to a sinusoid with a period of one year. Since the time intervals between measurements are irregular, and typically consist of one to two month gaps, the harmonic analysis was restricted by including only the annual, semi-annual, and quarterly harmonics (e.g. Djakovac et al., 2012). The temporal trends were calculated both for the whole study period (1972-2012) and for two shorter intervals: 1972-1988 and 1988-2012. These periods were selected considering that a cluster of events of exceptionally pronounced hypoxia in the late 1980s constituted a breakpoint in the time-series.

Graphical analyses were performed using Golden Software Grapher 9. Areal distribution of oxygen saturation percentage in the bottom layer and dynamic heights of the 30-dbar surface were calculated by Ocean Data View (ODV) software and Data-Interpolating Variational Analysis (DIVA), advanced gridding software built-in.

A parametric method based on sequential t-test analysis of regime shifts (Rodionov, 2004) was used to identify regime shifts for the Po River discharge and for the hypoxic events.

The non-parametric Mann-Kendall test was used to detect monotonic trends of number of hypoxic events observed along the profile Rovinj-Po River delta.

In the present work we define hypoxia as the condition when the dissolved oxygen is equal or lower than $2 \mathrm{~mL} \mathrm{O}_{2} \mathrm{~L}^{-1}$, according to Diaz and Rosenberg (2008), corresponding to $34-39 \%$ of saturation for the range of temperature in the period August-November $\left(12-19{ }^{\circ} \mathrm{C}\right)$.

\section{Results and discussion}

\subsection{Seasonal variations of dissolved oxygen (DO) and stratification}

In winter the NAd waters are well oxygenated throughout the water column (Fig. 1A-a, Appendix). The bottom layer becomes undersaturated with the onset of stratification in March on the western (more eutrophic) and in April on the eastern (oligotrophic) side of the profile Rovinj-Po River (Fig. 1). During spring and summer the oxygen content decreases progressively near the bottom during remineralisation of sedimenting organic matter, transported by riverine waters and produced by phytoplankton blooms in the surface layers (indicated by oxygen supersaturation). Bottom oxygen minima usually occur in September in the western and in October in the eastern areas. Afterwards, convective mixing of the water column progressively increases values reaching approximately the saturation during late November-December.

In the western waters (Fig. 1A-b, Appendix), which are under a more direct influence of freshwater discharges, the stratification is stronger and more variable than in the eastern waters (Table 1). In the eastern area the stratification is more related to the seasonal cycle of temperature and to the variability in the eastward advection of freshened waters that is frequent during late spring and summer (e.g. Degobbis et al., 2000; Mauri and Poulain, 2001). During the autumn these waters remain confined within frontal zones along the western coast.

Hypoxia can only occur in layers below the pycnocline that prevent oxygen diffusion from surface to lower layer (Rabalais et al., 2010). In the NAd, due to the strong seasonal stratification, small variations in the pycnocline strength would not significantly influence the oxygen content of the bottom waters. Moreover, in deeper layers, and particularly near the bottom, oxygen consumption during remineralisation processes prevails over photosynthetic production, limited by reduced sunlight penetration. The seasonal temperature cycle determines variations in the solubility of oxygen that are larger in the NAd surface $\left(1972-2012, \mathrm{t}_{\text {range }}=5.5-31 .{ }^{\circ} \mathrm{C}\right)$ than in bottom waters $(1972-2012$, $\left.\mathrm{t}_{\mathrm{range}}=6.7-22.1^{\circ} \mathrm{C}\right)$. The maxima in dissolved oxygen content are reached in the colder winter months along the western coastal waters, as also shown in the spatial climatological maps (Russo et al., 2012).

\subsection{Interannual variations in the oxygenation of bottom waters}

A cluster of hypoxic events (including a 1989 anoxia) was observed in the bottom layers along the profile Rovinj-Po River delta between the late 1980s and early 1990s (Fig. 2). This cluster of events involved both western and eastern areas of the NAd, as also shown by negative anomalies of oxygen volume ratios from the statistical model (Fig. 3). Other severe hypoxic events ( $\mathrm{DO}<1 \mathrm{~mL} \mathrm{~L}^{-1}$ ), with a variable spatial extent, were observed in 1972, 1977 and 2004. In contrast, after 1992 DO concentrations lower than $1 \mathrm{~mL} \mathrm{~L}^{-1}$ were observed only exceptionally, whereas hypoxic conditions were mostly limited to the western part of the investigated area, although somewhat less severe than during the 1970s and 1980s (Fig. 2). Values about $2 \mathrm{~mL} \mathrm{~L}^{-1}$ were measured in the central area only during some years. Seasonal hypoxic or anoxic events are more recurrent and last for longer periods in the western coastal areas than in offshore waters, particularly south of the Po Delta (Rinaldi et al., 1992). This area is considered eutrophic or hypertrophic,

\section{Table 1}

Means, ranges, standard deviations (SD), coefficients of correlation (r) and probabilities (p) for differences between surface and bottom density $\left(\Delta \sigma_{t} / \mathrm{kg} \mathrm{m}^{-3}\right)$ at 5 stations of the profile Rovinj-Po River delta from August to November in the periods 1972-1988, 1988-2012 and 1972-2012. The correlation was considered significant when $\mathrm{p}<0.05$.

\begin{tabular}{|c|c|c|c|c|c|c|}
\hline & & \multicolumn{5}{|c|}{ Stations } \\
\hline & & SJ108 & SJ101 & SJ103 & SJ105 & SJ107 \\
\hline \multirow[t]{5}{*}{ 1972-1988 } & Mean & 5.8 & 4.6 & 4.5 & 4.1 & 3.7 \\
\hline & Range & 12.1 & 11.5 & 16.8 & 8.3 & 5.7 \\
\hline & SD & 2.8 & 2.5 & 1.9 & 1.8 & 1.9 \\
\hline & $r$ & 0.231 & 0.169 & 0.107 & 0.193 & 0.292 \\
\hline & $\mathrm{p}$ & 0.129 & 0.185 & 0.286 & 0.162 & 0.066 \\
\hline \multirow[t]{5}{*}{ 1988-2012 } & Mean & 5.9 & 4.5 & 3.7 & 3.4 & 3.3 \\
\hline & Range & 22.3 & 14.4 & 7.5 & 7.8 & 7.5 \\
\hline & SD & 3.8 & 2.5 & 1.9 & 1.8 & 1.9 \\
\hline & $r$ & 0.087 & 0.138 & 0.033 & 0.017 & -0.049 \\
\hline & $\mathrm{p}$ & 0.206 & 0.104 & 0.374 & 0.437 & 0.317 \\
\hline \multirow[t]{5}{*}{ 1972-2012 } & Mean & 5.8 & 4.5 & 3.9 & 3.4 & 3.4 \\
\hline & Range & 22.3 & 14.6 & 16.8 & 8.4 & 7.5 \\
\hline & SD & 3.6 & 2.5 & 2.3 & 1.9 & 1.9 \\
\hline & $r$ & 0.077 & 0.141 & 0.08 & 0.009 & -0.021 \\
\hline & $\mathrm{p}$ & 0.204 & 0.067 & 0.187 & 0.459 & 0.408 \\
\hline
\end{tabular}




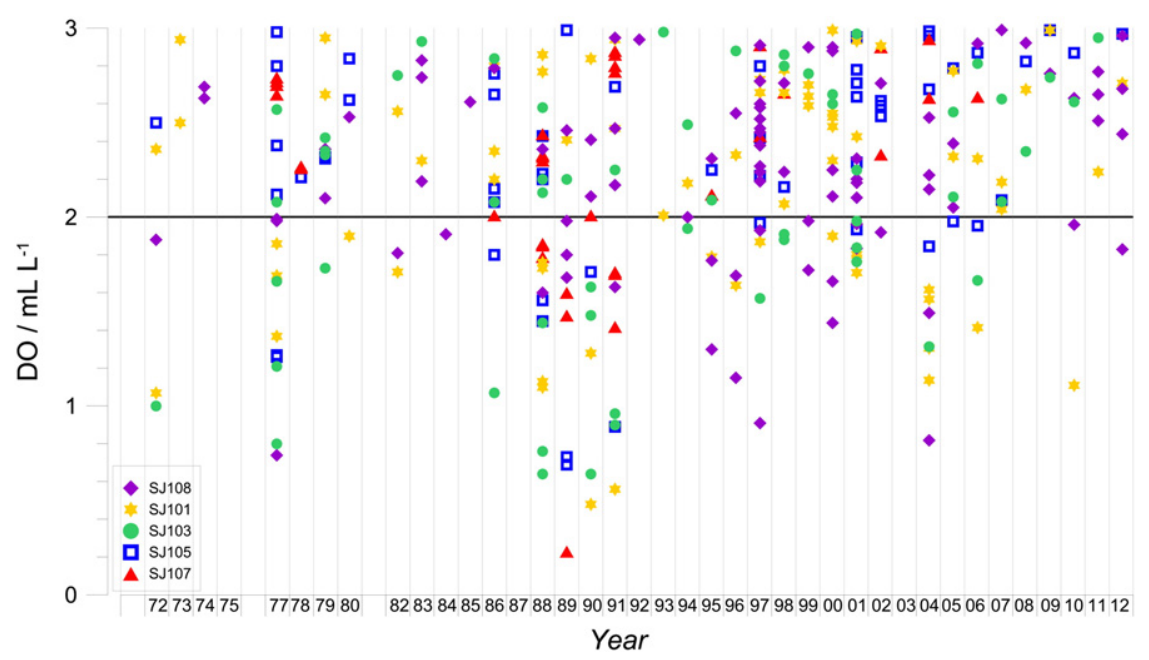

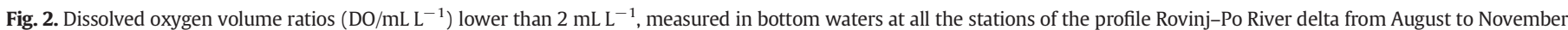
during the period 1972-2012. No data were available in years not indicated on the X-axis.

whereas in the rest of the NAd oligo- to mesotrophic conditions are dominant (Druon et al., 2004).

A significant positive trend for the oxygen volume ratio in the bottom layer was obtained for the period 1988-2012, although not for the entire 1972-2012 interval (Fig. 3), probably because of a lack of data for November, including those for the 1977 anoxia (Degobbis et al., 1979). A tendency to decrease both oxygen volume ratio and saturation percentage was detectable in the bottom layer $(\mathrm{p}<0.05)$ of the central-eastern waters during the period 1972-1988.

Significant increasing trends were detected over the period 1988-2012 both for DO volume ratios and percentage saturation (Fig. 3 and Fig. 3A, Appendix). Recent studies evidenced significant decreases of both chlorophyll $a$ concentration in surface open waters (by $0.11 \mu \mathrm{g} \mathrm{L}^{-1}$; Mozetič et al., 2009) and of phytoplankton abundance (of about three fold in the eastern area; Marić et al., 2012) during the period 1988-2007. This was the most probable reason for the observed increasing trend, because of reduced oxygen consumption in remineralisation processes. Decreasing trends of surface chlorophyll $a$ in NAd were also recently observed by analysing Med Regional SeaWiFS RAN-My Ocean satellite data for the period 1998-2009 (Coppini et al., 2013).

Analysing the time series of the total number of hypoxic events (DO $\leq 2 \mathrm{~mL} \mathrm{~L}^{-1}$ ) observed at all the stations from August to November of the period 1988-2012, a significant decreasing trend was evidenced by the Mann-Kendall test, at a significance level $\alpha=0.05$.

The density difference between bottom and surface waters (a measure of stratification degree) varied markedly along the profile Rovinj-Po delta (Table 1). The median value and the variability were much larger in the area under the more direct influence of freshwater discharge, compared with the rest of the profile, although an eastward decreasing gradient was well evident. No significant trends were obtained for the entire studied period nor for the periods before and after 1988. However, in the more recent period (1988-2012) stratification was less developed, due to reduction of freshwater discharge (Fig. 2A, Appendix).

\subsection{The role of geostrophic circulation in the hypoxic events}

Based on available data, six cases of bottom oxygen saturation distributions in the NAd were compared to geostrophic current fields during an initial (August) and a final phase (November) of hypoxia development. These examples were plotted by decreasing extents of the hypoxia events. The data used were collected in the open waters, more than 10-12 nautical miles off the coast.
During 1977, in conditions of extremely low barometric pressure and increased rainfall, the Po River flow rate was exceptionally high until November (Fig. 2A, Appendix), with freshets in May, September and October, ranging from 7000 to $8000 \mathrm{~m}^{3} \mathrm{~s}^{-1}$ (Degobbis et al., 2000). Freshwater "flooded" the entire area markedly increasing the water column stratification (Degobbis et al., 1979). In these conditions the organic matter load produced and decomposed was much higher than usual, particularly in the eastern part of the NAd. As a consequence, bottom hypoxia (DO saturation $<30 \%$ ) occurred in August over a major part of the basin (Fig. 4a). Two hypoxic zones coincided with anticyclonic circulation cells that were also described by Rachev et al. (2006). Remarkably, the lowest values were registered far from the Po Delta, in the deeper part of the investigated area $(40 \mathrm{~m})$. Other studies indicated that prolonged anoxia occurred in a large area until November, causing a mass mortality of benthic organisms (Stefanon and Boldrin, 1980) and afterwards, in December, the oxygen was redistributed throughout the water column by convective mixing (Degobbis et al., 1979).

In August 1983 extremely low oxygen saturation ratios $(<15 \%)$ were measured within a cyclonic gyre, located southeast of the Po Delta (Fig. 4a). This hypoxic event was probably a relatively short episode, as in October, along the profile Rovinj-Po River delta, the bottom values (40-90\%) were near the long-term averages (CMR data base). Moreover, while a flow rate peak of the Po River (up to $5000 \mathrm{~m}^{3} \mathrm{~s}^{-1}$ ) occurred in spring, during the rest of this year the values were around the long-term averages or even markedly lower in autumn. Concurrently, during the late summer of 1983 mortalities of benthic organisms were observed in some coastal areas of the NAd as in the Gulf of Trieste (Faganeli et al., 1985; Stachowitsch, 1984).

In August 1972 the bottom DO saturation ratios were about 60\% in the area of an anticyclonic gyre extending from the Po Delta again towards the southeast (Fig. $4 \mathrm{a}$ ). In the rest of the region the values were higher than the average. In this year the Po River flow rate was markedly increased in February and March, when the general cyclonic circulation prevailed, exporting southward a major part of the freshened water. This prevented a significant impact of riverine nutrients on the ecosystem and ultimately on the summer bottom oxygen budget. However, hypoxia (DO saturation ratio $<20 \%$ ) occurred in November, although in a relatively localised western area (stations SJ101 and SJ103).

In November 1989, anoxia developed over about $1000 \mathrm{~km}^{2}$ in a large area off the Istrian coast, with mass mortality of benthic organisms, but severe mortality occurred also in the rest of the area (Degobbis et al., 1993). Anoxia or near-anoxic conditions occurred within both the eastern cyclonic and the western anticyclonic gyres (Fig. 4b). In August of this year a near-hypoxic area (30-40\%) of a similar spatial extent and 

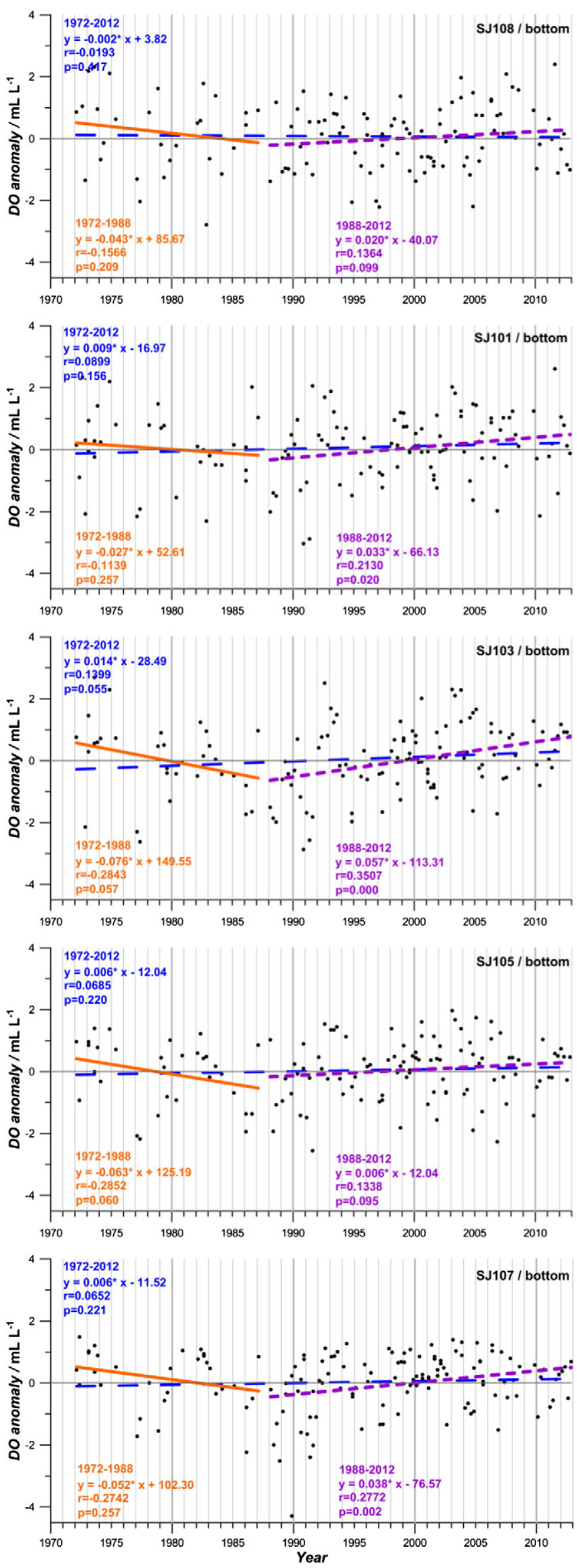

location (SE off the Po Delta) as in August 1983 was detected. The Po flow rate was relatively high only in April (up to $5000 \mathrm{~m}^{3} \mathrm{~s}^{-1}$ ), whereas in the other months the values were lower than the annual long-term average (1496 $\mathrm{m}^{3} \mathrm{~s}^{-1}$; Cozzi and Giani, 2011). This strongly indicated that in 1989 the circulation played a relatively major role with respect to the eutrophication pressure which had a more relevant impact during the 1977 anoxia event.

In November 2006 a large anticyclonic gyre in open NAd waters coincided with a central hypoxic area $(<20 \%$; Fig. $4 b)$. During this year the Po flow rate was also extremely low (Fig. 2A, Appendix), and a very persistent cyclonic gyre might be the principal cause of the observed hypoxia.

Autumn 2003 is an example of a year when hypoxic event did not develop at the basin scale. In November 2003, well oxygenated bottom waters occupied the entire investigated area (Fig. 4b). Most of the area was characterised by a cyclonic circulation, drawing waters from the central Adriatic. Even within the anticyclonic gyre that developed off the Po Delta the bottom oxygen content was near saturation, similar to the preceding months. In that year vertical mixing and the reactivation of the "winter" cyclonic circulation probably started already at the beginning of this month, as deduced from SeaWiFS chlorophyll $a$ maps (http://gos.ifa.rm.cnr.it/adricosm/). These processes were also favoured by minimal presences of freshened water, due to the extremely low Po River flow rate over the year (Fig. 2A, Appendix).

An anticyclonic gyre frequently appears with the eastern branch that extended up to the Istrian coast, named the Istrian Coastal Countercurrent (ICCC; corresponding to "negative" values in Fig. 5), flowing southwards and contrasting the northward Eastern Adriatic Current (EAC) that carries waters from the central Adriatic (Supić et al., 2000). An intensification of the ICCC may indicate a more developed anticyclonic gyre, implying also a more stable gyre system. In fact, in August, DO $<2 \mathrm{~mL} \mathrm{~L}^{-1}$ coupled with higher ICCC velocity was measured not only in the years presented above, but also in several other cases (Fig. 5) as from 1988 to 1993 when the ICCC was especially intense. In contrast, hypoxic events in 2007 did not correspond to a well-developed ICCC when the Po flow rates were extremely low (Fig. 2A, Appendix) and in 2009, when a maximum flow rate occurred in spring earlier than usual. In some cases of slower ICCC, hypoxia can also develop, like in the periods 2000-2002 and 2010-2012. However, in these cases the events were restricted to the western area, off the Po Delta, when the eutrophication pressure was more pronounced.

The gyres cause advection of riverine waters (enriched in nutrients) eastwards, up to the Istrian coast. The persistence of the gyres through several months in the stratification period seems to be an essential factor which increases the residence time of the bottom waters within the NAd. These gyres favour accumulation and settling of organic matter produced in surface waters, with consequent progressive oxygen consumption in bottom layers even in the eastern part. Moreover the persistence of these gyres could enhance the entrapping and the aggregation of colloids and particles leading to the formation of mucilaginous aggregates which occurred in the summer of 1988, 1989, 1990 and 1991 (Precali et al., 2005), 1997 (Cozzi et al., 2004), 2000, 2002 (Precali et al., 2005), 2004 (Faganeli et al., 2009; ICRAM, 2004; Riccardi et al., 2010) and in the autumn of 2006 (Regione Emilia Romagna, 2009).

The duration of the hypoxic/anoxic events in early autumn also depends on blowing frequency of north-easterly winds ("Bora"; e.g. Cushman-Roisin et al., 2001) that enhance surface cooling and convective mixing in the water column, with a consequent reoxygenation of bottom waters (Boldrin et al., 2009).

Fig. 3. Differences of dissolved oxygen volume ratios from the average statistical model (DO anomaly/mL L ${ }^{-1}$ ) in bottom waters at 5 stations of the profile Rovinj-Po River delta from August to November during the period 1972-2012. Trends were calculated for the periods 1972-1988 (solid line), 1988-2012 (dotted line) and 1972-2012 (dashed line). The correlation was considered significant when $\mathrm{p}<0.05$. 

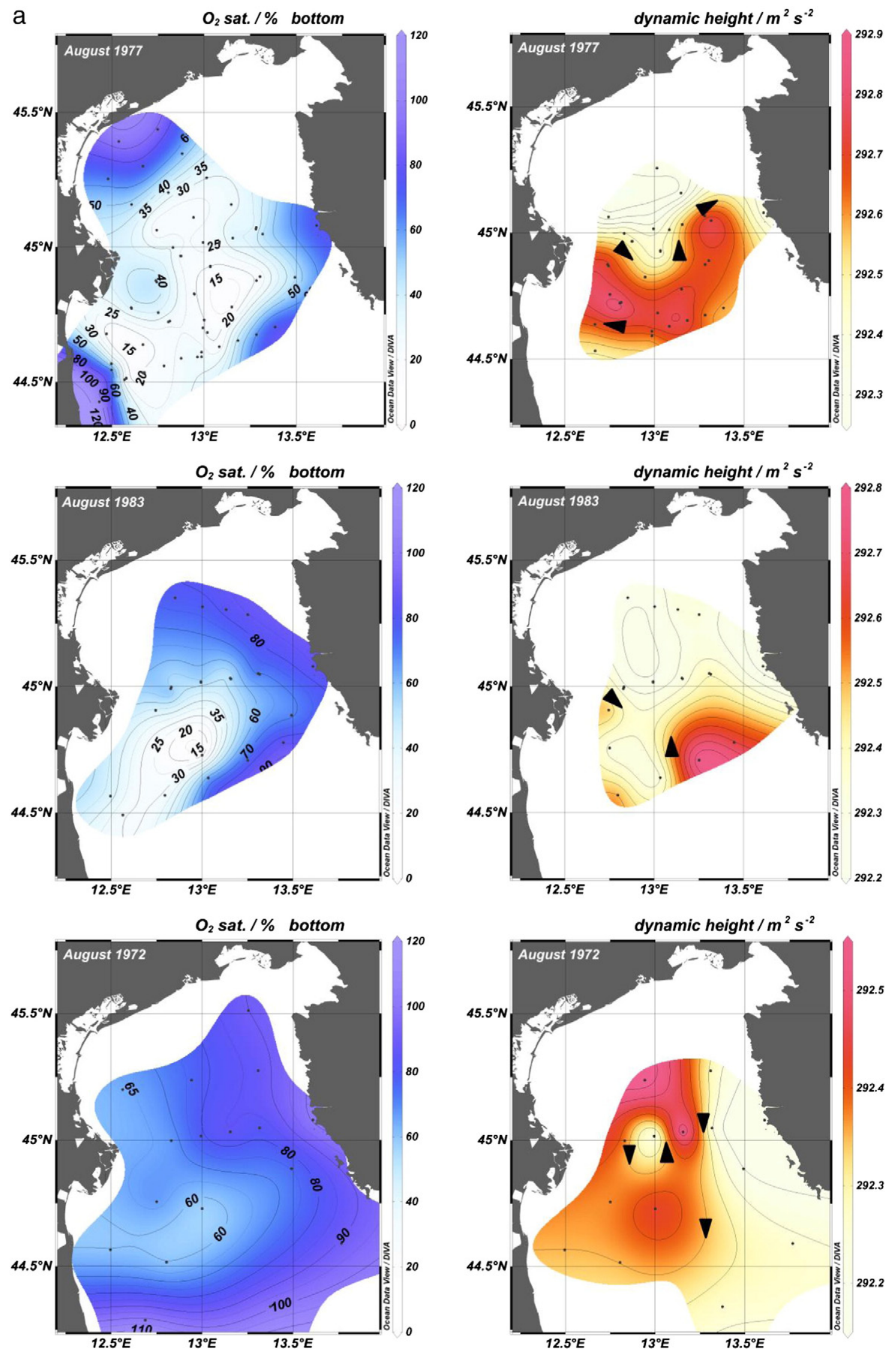

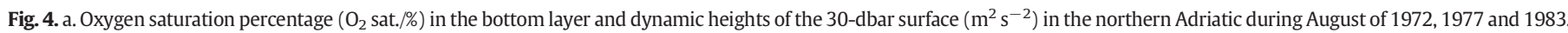

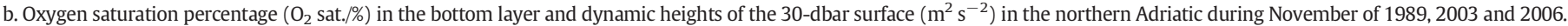


b
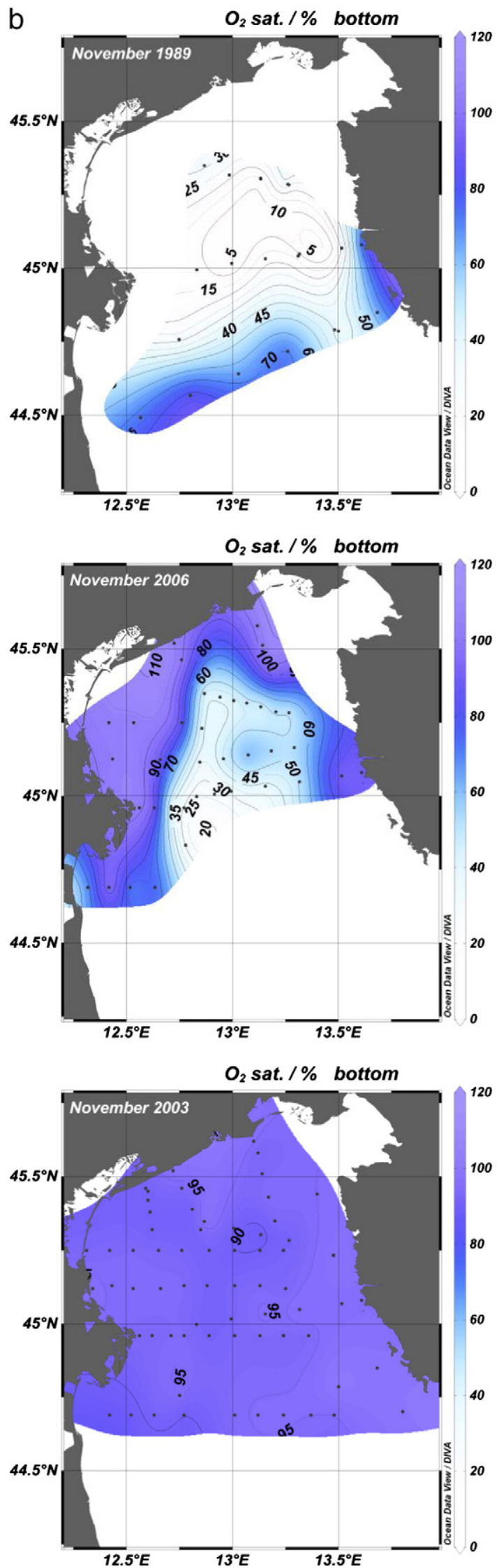

dynamic height $/ \mathrm{m}^{2} \mathrm{~s}^{-2}$
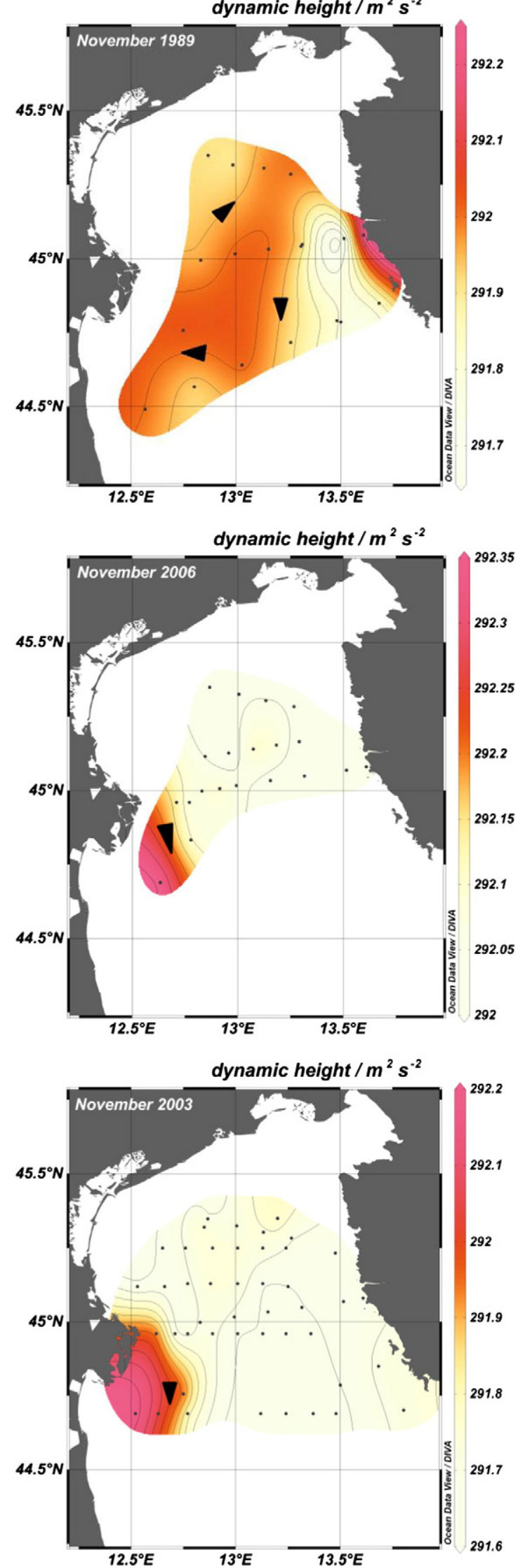

Fig. 4 (continued). 


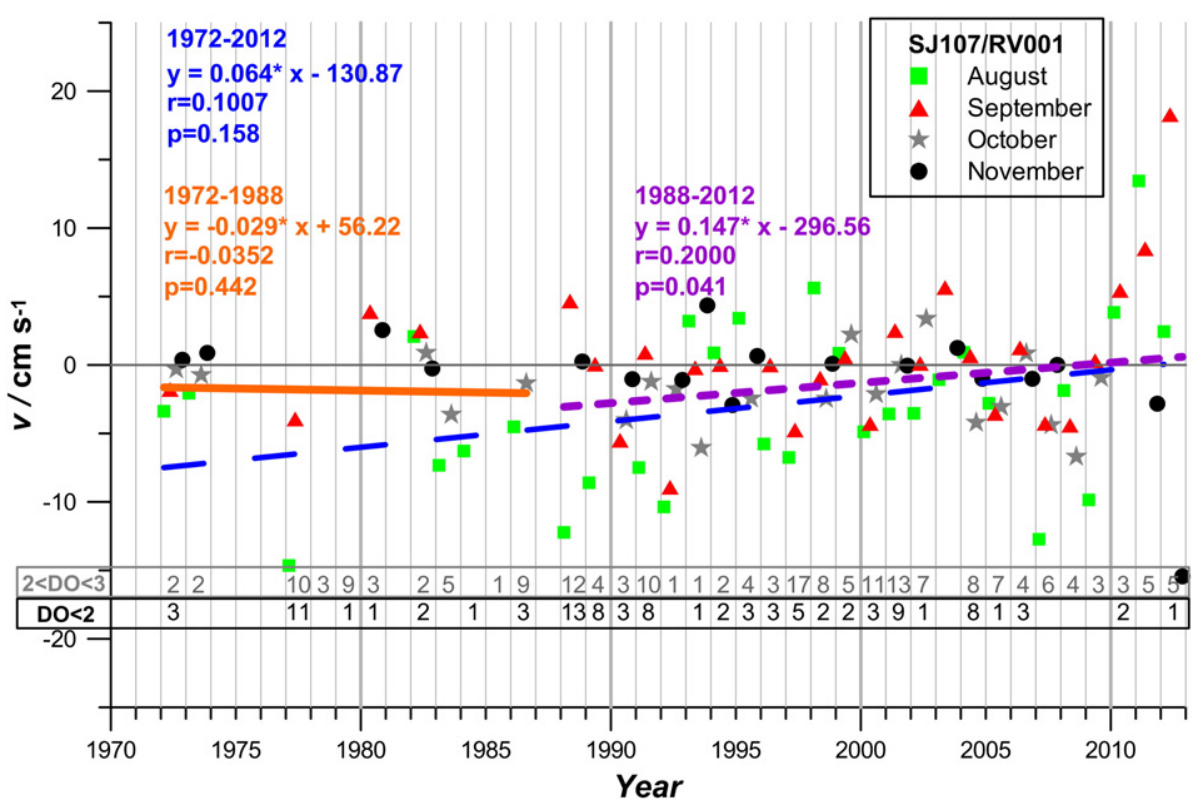

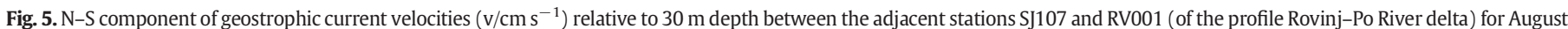

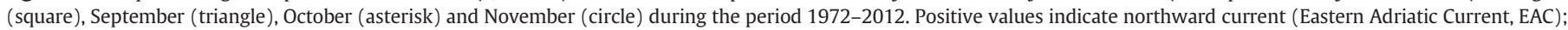

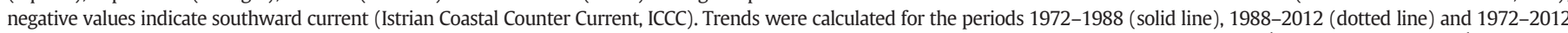

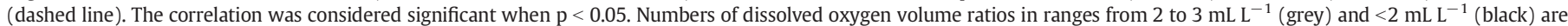
reported in horizontal rows.

\subsection{Temperature effect on oxygenation}

Significant linear inverse correlations $(p<0.05)$ between differences from the mean statistical models of oxygen volume ratio and temperature differences were found for almost all the stations at the surface (Fig. 6). In bottom waters there was no correlation in the western waters, whereas in the central and eastern areas the correlations were significant, although positive.
The time series showed a significant $(\mathrm{p}<0.05)$ decreasing trend of surface oxygen in eastern waters during the period 1988-2012, combined with a significant increasing temperature trend (Fig. 7). However, this trend was not evident in the previous period (1972-1988). Simultaneously, a significant decreasing trend in oxygen saturation anomaly is also observed (Fig. 3A, Appendix). This general reduction of oxygen content of the surface layer in the period 1988-2012 could be explained by a reduction of phytoplankton blooms, which indeed was observed

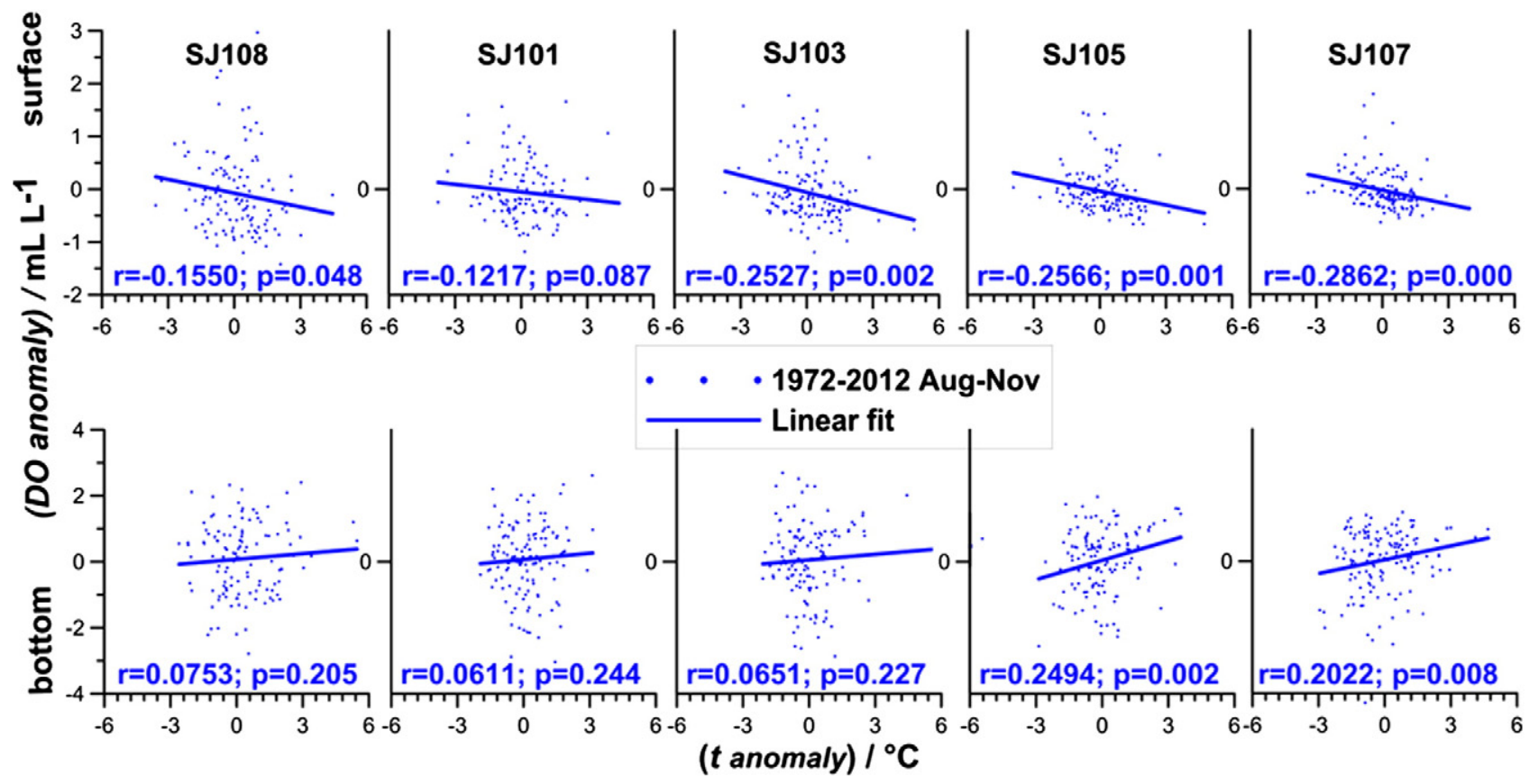

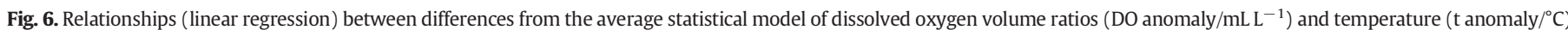
in surface waters at 5 stations of the profile Rovinj-Po River delta from August to November during the period 1972-2012. 

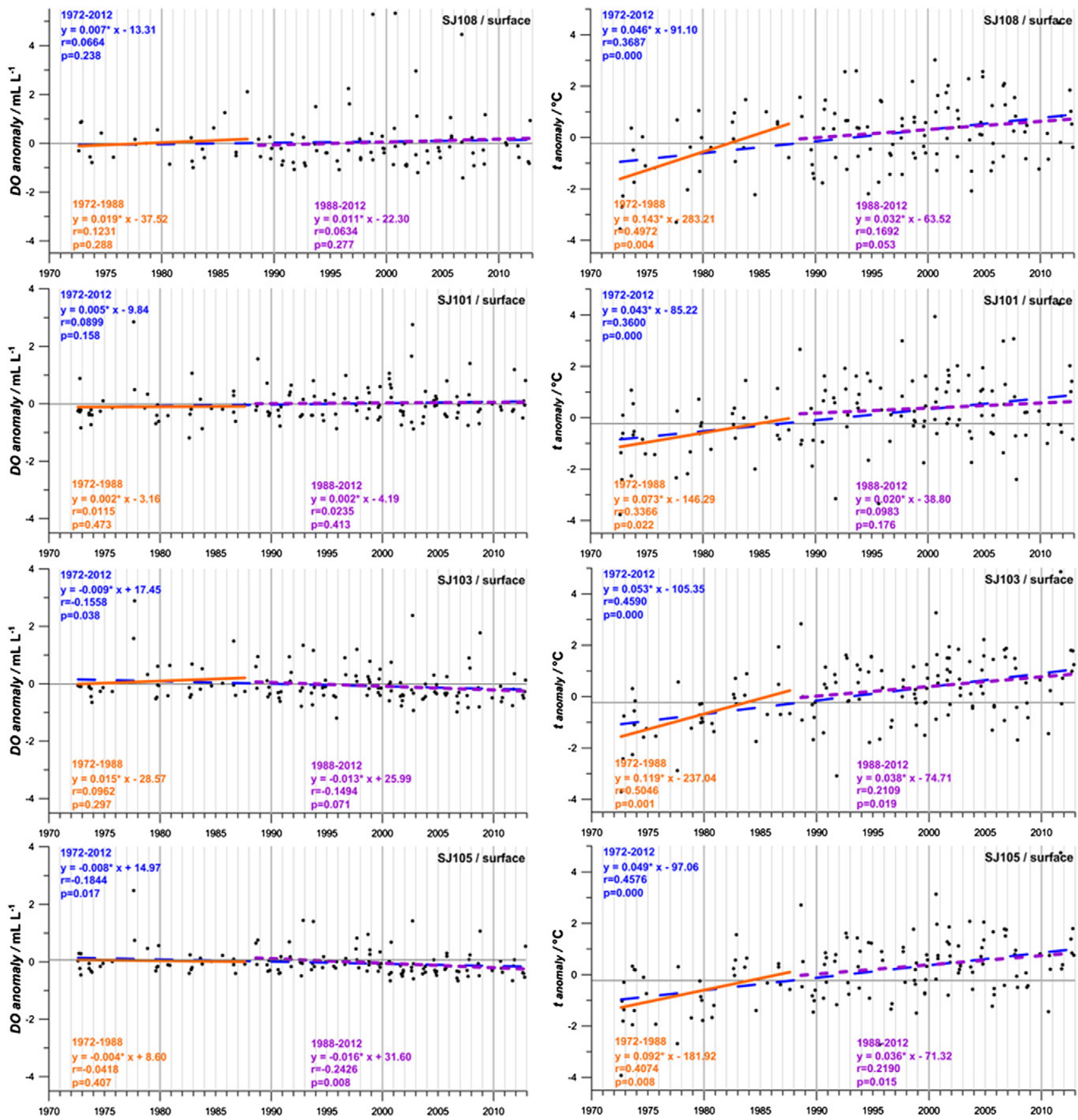

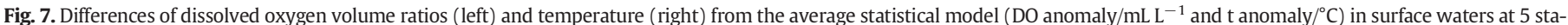

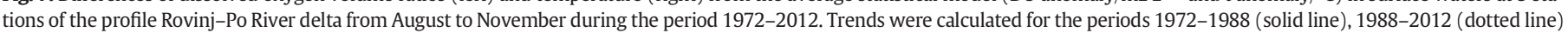
and 1972-2012 (dashed line). The correlation was considered significant when $\mathrm{p}<0.05$.

both as chlorophyll $a$ by Mozetič et al. (2009) and as cell numbers (Marić et al., 2012).

Beside the oligotrophication, these inverse relationships at the surface could be due to temperature effect on oxygen solubility, whereas the positive correlations in near-bottom waters could be related to the advection of warmer southern waters, richer in oxygen. This hypothesis was supported by a significant $(\mathrm{p}<0.002$ ) relationship between bottom salinity and oxygen difference from the statistical model (CMR, unpub. data), as well as from frequency increases of EAC intrusions in the study area.
Nevertheless, it should be noted that the significant warming trend of surface waters at all the stations $(p<0.001$; Fig. 7$)$ supports similar finding in various areas of the NAd (Giani et al., 2012; Russo et al., 2002; Tedesco et al., 2007). Moreover, surface warming in the western and eastern Mediterranean Sea has been well evidenced by trends of SST obtained analysing AVHRR-derived maps over 1985-2008 (Skliris et al., 2011), with much higher warming rates during spring and summer than in autumn and winter.

In the shallow western coastal areas south of the Po River delta, the warming could have a higher impact than in offshore waters, due both 
to a decreased solubility effect and to an enhancement of benthic and sub-pycnocline respiration rates, as also suggested by Malej and Malačič (1995).

\subsection{The role of circulation and temperature trends in occurrence of hypoxia} at basin scale

The analysis of the available data series pointed out that the frequency of hypoxia events in the NAd during the studied period (1972-2012) corresponded mainly to changes in the circulation patterns, characterised by the concurrent formation of cyclonic and anticyclonic gyres. An anticyclonic gyre, which develops in the eastern part of the investigated area, seems to be one of the most critical factors favouring bottom hypoxic/ anoxic events at the basin scale. This gyre generates a southward current, the Istrian Coastal Countercurrent (ICCC) that is opposite to the northward Eastern Adriatic Current (EAC), reducing significantly the water exchange between the northern and central Adriatic (Supić et al., 2000). The presence of this anticyclonic gyre, as well as the ICCC is evident in the satellite chlorophyll maps (http://gos.ifa.rm.cnr.it/adricosm/). When the ICCC was particularly intense, very marked hypoxia or even anoxia occurred over large areas of the central and eastern NAd, causing benthic mass mortality, like, for example, in November 1989 (Degobbis et al., 1993). In years when the ICCC was weak or absent, hypoxic events did not occur or were confined to the western area.

The mechanism by which hypoxia or anoxia events extend to large areas of the NAd basin is very probably related to an entrapping of freshened waters, formed in the area off the Po River delta, and thus rich in nutrients and organic matter within the gyres. The persistence of these gyres is high (up to several months; e.g. Orlić et al., 2013) leading to a gradual sedimentation of particulate organic matter with a consequent oxygen consumption in the bottom layer during the stratification period (spring-mid autumn). In this layer the production by photosynthesis is not sufficient to replace the oxygen used during remineralisation of settling particulate organic matter, due to light limitation (CMR data base). Thus, oxygen depletion is more marked within the central area of these gyres, where the water dynamics is at a minimum.

A decreasing trend of freshwater discharges since the 1980s (Cozzi and Giani, 2011) and the halving of the Po River phosphorus load, after the ban of phosphates based detergents during late 1980s (Degobbis et al., 2000 and references therein), were probably the principal causes of oligotrophication (Djakovac et al., 2012; Giani et al., 2012; Solidoro et al., 2009). The diminishing phytoplankton abundances (Marić et al., 2012) and biomass (Mozetič et al., 2009), combined with the reduction of gyre formation observed in the present work, caused a decrease of the hypoxia frequency.

The warming trend might have enhanced deoxygenation of upper layers, whereas this was not yet observed in bottom waters. Our results did not evidence a significant increase of water column stratification, due to surface warming during summer and autumn. However, climate changes could affect the seasonal circulation, enhancing the stability of the gyres and increasing the residence time of the bottom waters. This would be critical for the development of hypoxia events.

The NAd is one of the few cases of coastal areas which experienced a marked reduction of eutrophication pressure with concurrent benefits for the bottom oxygen budget. Similar changes have occurred in Mersey estuary (Jones, 2006), Delaware Bay (Sharp, 2010) and the Inner Stockholm Archipelago (Karlsson et al., 2010; Steckbauer et al., 2011), where a decrease of nutrient discharges proved to be beneficial in increasing bottom water oxygenation. In other areas around the world signs of reversal of eutrophication processes have been observed (e.g. Danish coastal areas and Black Sea; Steckbauer et al., 2011; McQuatter-Gollop et al., 2009), although oxygen recovery was not observed or documented.

Further long-term investigations are needed to verify if the observed oxygenation trends will continue, according to changes of nutrient anthropogenic inputs and circulation patterns to forecast the response of the plankton and benthic communities. Understanding of climatic fluctuations, influencing the circulation regime in the northern Adriatic, is also an important task, leading to explain and possibly forecast hypoxia events. To fulfil these aims an observing system in open waters is essential, combining research cruises, networking of oceanographic buoys (with near bottom sensors) and satellite data.

\section{Conclusions}

Statistical analyses of the available data showed that in the NAd the oxygen content of the bottom layer increased since the early 1990s up to 2012 with respect to the 1970s and 1980s. Severe hypoxic events, observed during the late 1980s and early 1990s, were extended up to the eastern, more oligotrophic area. In contrast, after 1992 large scale hypoxia occurred only rarelly (e.g. in 2004), while in the western eutrophic area hypoxic conditions remained quite frequent, although with reduced intensity.

A warming trend might have enhanced deoxygenation of upper layers, whereas this was not observed in bottom waters. Moreover, the obtained results did not reveal a significant increase in stratification of the water column. Thus, it was concluded that the marked frequency reduction of large scale hypoxia events observed since 1990s in the NAd was mainly due to changes in circulation patterns, in addition, to a reduction of phytoplankton abundance as a consequence of decreased freshwater discharge.

It was assumed that an anticyclonic gyre, developed in the eastern part of the investigated area, might play an important role in the hypoxic/anoxic events at large scales. The stability of this gyre appeared to be reduced since the 1990s, as indicated by decreasing velocities of the Istrian Coastal Countercurrent (ICCC). This southward current is generated by the anticyclonic gyre under conditions of reduced water exchange between the northern and the central Adriatic.

\section{Acknowledgements}

The data to update the long time series were kindly provided by CMR Rovinj (LPME).

This work was principally supported by the Ministry of Science, Education and Sport of the Republic of Croatia projects 0982705-2731 and 0982705-2707. This work is a contribution to PERSEUS FP7-OCEAN2011 (Contract \# 287600) project and to the MEDSEA (Contract \# 265103) project. The authors thank all technicians and scientists that contributed to the collection and elaboration of data especially to Dr. Robert Precali, and to the crew of RV "Vila Velebita" for the technical help in sampling during cruises.

The used data were collected during several research projects financed by Croatian governmental, public and private institutions, as well as in the framework of EC INTERREG III projects, of the Joint Italian-Croatia-Slovenian Commission for the Protection of the Adriatic Sea (ASCOP Project), of Alpe Adria project on mucilages, of the MAT (Mucilages in the Adriatic and Tyrrhenian seas) project, financed by the Italian Ministry of the Environment, and of the Croatian-USA collaboration (granted by NSF and Smithsonian Institute).

Po River discharges were kindly provided by ARPA Emilia Romagna Servizio Idro-Meteo Clima, Parma, Italy.

The authors are very grateful to Dr. Lisa Levin, the guest editor, for helpful suggestions and useful indications to improve our manuscript.

\section{Appendix A. Supplementary data}

Supplementary data to this article can be found online at http://dx. doi.org/10.1016/j.jmarsys.2014.08.001. 


\section{References}

Barmawidjaja, D.M., van der Zwaan, G.J., Jorissen, F.J., Puskaric, S., 1995. 150 years of eutrophication in the northern Adriatic Sea: evidence from a benthic foraminiferal record. Mar. Geol. 122, 367-384.

Boldrin, A., Carniel, S., Giani, M., Marini, M., Bernardi Aubry, F., Campanelli, A., Grilli, F Russo, A., 2009. The effects of bora wind on physical and biogeochemical properties of stratified waters in the northern Adriatic. J. Geophys. Res. 114, C08S92.

Coppini, G., Lyubarstev, V., Pinardi, N., Colella, S., Santoleri, R., Christiansen, T., 2013. The use of ocean-colour data to estimate chl-a trends in European seas. Int. J. Geosci. 4 927-949.

Cozzi, S., Giani, M., 2011. River water and nutrient discharges in the Northern Adriatic Sea: current importance and long term changes. Cont. Shelf Res. 31, 1881-1893.

Cozzi, S., Ivančić, I., Catalano, G., Djakovac, T., Degobbis, D., 2004. Dynamics of the oceanographic properties during mucilage appearance in the Northern Adriatic Sea: analysis of the 1997 event in comparison to earlier events. J. Mar. Syst. 50, 223-241.

Crema, R., Castelli, A., Prevedelli, D., 1991. Long term eutrophication effects on macrofaunal communities in northern Adriatic Sea. Mar. Pollut. Bull. 22 (10), 503-508.

Cushman-Roisin, B., Gačić, M., Poulain, P.-M., Artegiani, A. (Eds.), 2001. Physical Oceanography of the Adriatic Sea. Kluwer Academic Publishers, Dordrecht, The Netherlands (304 pp.)

Degobbis, D., Smodlaka, N., Pojed, I., Škrivanić, A., Precali, R., 1979. Increased eutrophication of the northern Adriatic Sea. Mar. Pollut. Bull. 10, 298-301.

Degobbis, D., Travizi, A., Jaklin, A., 1993. Meccanismi di formazione di strati di fondo ipossici e anossici nel bacino dell'Adriatico settentrionale e reazioni delle comunità bentoniche, pp. 57-62. Ipossie e anossie di fondali marini. In: Orel, G., Fonda Umani, S., Aleffi, F. (Eds.), L'Alto Adriatico e il Golfo di Trieste. Regione Autonoma Friuli-Venezia Giulia, Direzione regionale dell'Ambiente, Trieste (104 pp.).

Degobbis, D., Precali, R., Ivancic, I., Smodlaka, N., Fuks, D., Kveder, S., 2000. Long-term changes in the northern Adriatic ecosystem related to anthropogenic eutrophication. Int. J. Environ. Pollut. 13, 495-533.

Diaz, R.J., 2001. Overview of hypoxia around the world. J. Environ. Qual. 30, 275-281.

Diaz, R.J., Rosenberg, R., 2008. Spreading dead zones and consequences for the marine ecosystems. Science 321, 926-929.

Djakovac, T., Degobbis, D., Supić, N., Precali, R., 2012. Marked reduction of eutrophication pressure in the northeastern Adriatic in the period 2000-2009. Estuar. Coast. Shelf Sci. $115,25-32$.

Doney, S.C., 2013. Marine ecosystems, biogeochemistry, and climate. Int. Geophys. 103 817-842.

Druon, J.N., Schrimpf, W., Dobricic, S., Stips, A., 2004. Comparative assessment of large-scale marine eutrophication: North Sea area and Adriatic Sea as case studies. Mar. Ecol. Prog. Ser. 272, 1-23.

Faganeli, J., Avcin, A., Fanuko, N., Malej, A., Turk, V., Tusnik, P., Vriser, B., Vukovic, A., 1985 Bottom layer anoxia in the central part of the Gulf of Trieste in the late summer of 1983. Mar. Pollut. Bull. 16, 75-78.

Faganeli, J., Ogrinc, N., Kovač, N., Kukovec, K., Falnoga, I., Mozetič, P., Bajt, O., 2009. Carbon and nitrogen isotope composition of particulate organic matter in relation to mucilage formation in the northern Adriatic Sea. Mar. Chem. 114, 102-109.

Falkowski, P.G., Algeo, T., Codispoti, L., Deutsch, C., Emerson, S., Hales, B., Huey, R.B., Jenkins, W.J., Kump, L.R., Levin, L.A., Lyons, T.W., Nelson, N.B., Schofield, O.S., Summons, R., Talley, L.D., Thomas, E., Whytney, F., Pilcher, C.B., 2011. Ocean deoxygenation: past, present, and future. Eos 92, 46.

Giani, M., Djakovac, T., Degobbis, D., Cozzi, S., Solidoro, C., Fonda Umani, S., 2012. Recent changes in the marine ecosystems of the northern Adriatic Sea. Estuar. Coast. Shelf Sci. 115, 1-13.

Gray, J.S., Wu, R.S.-S., Or, Y.Y., 2002. Effects of hypoxia and organic enrichment on the coastal marine environment. Mar. Ecol. Prog. Ser. 38, 249-279.

ICRAM, Ministero dell'Ambiente e del territorio, 2004. Monitoraggio delle mucillagini ne mare Adriatico centro-settentrionale. http://www.naturaitalia.it/ (In Italian).

Jones, P.D., 2006. Water quality and fisheries in the Mersey estuary, England: a historical perspective. Mar. Pollut. Bull. 53, 144-154

Justić, D., Legović, T., Sandrini, L.R., 1987. Trends in oxygen content 1911-1984 and occurrence of benthic mortality in the northern adriatic sea. Estuar. Coast. Shelf Sci. 25 , $435-445$.

Karlsson, O.M., Jonsson, P.O., Lindgren, D., Malmaeus, J.M., Stehn, A., 2010. Indications of recovery from hypoxia in the Inner Stockholm Archipelagoo. Ambio 39, 486-495.

Keeling, R.F., Kortzinger, A., Gruber, N., 2010. Ocean deoxygenation in a warming world. Annu. Rev. Mar. Sci. 2, 199-229.

Kollmann, H., Stachowitsch, M., 2001. Long-term changes in the benthos of the northern Adriatic Sea: a phototransect approach. Mar. Ecol. 22, 135-154.

Krajcar, V., 2003. The climatology of geostrophic currents in the northern Adriatic. Geofizika 20, 105-114

Lotze, H.K., Lenihan, H.S., Bourque, B.J., Bradbury, R.H., Cooke, R.G., Kay, M.C., Kidwell, S.M. Kirby, M.X., Peterson, C.H., Jackson, J.B.C., 2006. Depletion, degradation, and recovery potential of estuaries and coastal seas. Science 312, 1806-1809.

Malej, A., Malačič, V., 1995. Factors affecting bottom layer oxygen depletion in the Gulf of Trieste (Adriatic Sea). Ann. Istrian Mediterr. Stud. 6, 33-42.

Marić, D., Kraus, R., Godrijan, J., Supić, N., Djakovac, T., Precali, R., 2012. Phytoplankton response to climatic and anthropogenic influence in the north-eastern Adriatic during the last four decades. Estuar. Coast. Shelf Sci. 115, 98-112.

Mauri, E., Poulain, P.-M., 2001. Northern Adriatic Sea surface circulation and temperature/ pigment fields in September and October 1997. J. Mar. Syst. 29, 51-67.
McQuatter-Gollop, A. Gilberrt, A.J., Mee, L.D., Vermaat, J.E., Artioli, Y., Humborg, C., Wulff, F., 2009. How well do ecosystem indicators communicate the effects of anthropogenic eutrophication? Estuar. Coast. Shelf Sci. 82, 583-596.

Mozetič, P., Solidoro, C., Cossarini, G., Socal, G., Precali, R., Francé, J., Bianchi, F., Vittor, C., Smodlaka, N., Fonda Umani, S., 2009. Recent trends towards oligotrophication of the Northern Adriatic: evidence from chlorophyll a time series. Estuar. Coasts 33, 362-375.

Orlić, S., Najdek, M., Supić, N., Ivančić, I., Fuks, D., Blažina, M., Šilović, T., Paliaga, P., Godrijan, J., Marić, D., 2013. Structure and variability of microbial community at transect crossing a double gyre structure (north-eastern Adriatic Sea). Aquat. Microb. Ecol. 69, 193-203.

Ott, J., 1992. The Adriatic benthos: problems and perspectives. In: Colombo, G., Ferrari, I., Ceccherelli, V.U., Rossi, R. (Eds.), Marine Eutrophication and Population Dynamics 25th European Marine Biology Symposium. Olsen \& Olsen, Fredensborg, pp. 367-378.

Precali, R., Giani, M., Marini, M., Grilli, F., Ferrari, C.R., Pečar, O., Paschini, E., 2005. Mucilaginous aggregates in the northern Adriatic in the period 1999-2002: typology and distribution. Sci. Total Environ. 353, 10-23.

Rabalais, N.N., Turner, R.E., Wiseman, W.J. Jr, 2002. Gulf of Mexico hypoxia, a.k.a. "the dead zone". Annu. Rev. Ecol. Syst. 33, 235-263.

Rabalais, N.N., Diaz, R.J., Levin, L.A., Turner, R.E., Gilbert, D., Zhang, J., 2010. Dynamics and distribution of natural and human-caused hypoxia. Biogeosciences 7, 585-619.

Rachev, N., Catalano, G., Crisciani, F., Cantoni, C., Purini, R., 2006. On the dynamical conditions concomitant with the bottom anoxia in the Northern Adriatic Sea: a numerical case study for the 1977 event. Il Nuovo Cimento 29, 673-693.

Regione Emilia Romagna, 2009. Eutrofizzazione delle acque costiere dell'Emilia Romagna. Rapporto annuale 2007. Centro Stampa giunta regionale, p. 171 (2009).

Riccardi, M., Guerrini, F., Serrazanetti, G.P., Ventrella, V., Pagliarani, A., Pistocchi, R., 2010. Lipid and DNA features of Gonyaulax fragilis (Dinophyceae) as potential biomarkers in mucilage genesis. Harmful Algae 9, 359-366.

Rinaldi, A., Montanari, G., Ghetti, A., Ferrari, C.R., 1992. Anossie nelle acque costiere dell'Adriatico nord-occidentale. Loro evoluzione e conseguenze sull'ecosistema bentonico. Biol. Mar. Suppl. Notiziario S.I.B.M. 1, 79-89 (In Italian).

Rodionov, S.N., 2004. A sequential algorithm for testing climate regime shifts. Geophys. Res. Lett. 31, L09204.

Russo, A., Rabitti, S., Bastianini, M., 2002. Decadal climatic anomalies in the northern Adriatic Sea inferred from a new oceanographic data set. Mar. Ecol. 23 (supplement 1), 340-351.

Russo, A., Carniel, S., Sclavo, M., Krzelj, M., 2012. Climatology of the northern-central Adriatic Sea. In: Wang, S.Y. (Ed.), Modern Climatology. InTechOpen, pp. 177-212.

Sangiorgi, F., Donders, T.H., 2004. Reconstructing 150 years of eutrophication in the north-western Adriatic Sea (Italy) using dinoflagellate cysts, pollen and spores. Estuar. Coast. Shelf Sci. 60, 69-79.

Sharp, J.H., 2010. Estuarine oxygen dynamics: what can we learn about hypoxia from long-term records in the Delaware Estuary? Limnol. Oceanogr. 55, 535-548.

Skliris, N. Sofianos, S. Gkanasos, A Mantziafou, A Vervatis, V., Axaopoulos, P., Lascaratos, A., 2011. Decadal scale variability of sea surface temperature in the Mediterranean Sea in relation to atmospheric variability. Ocean Dyn. 62, 13-30.

Solidoro, C., Bastianini, M., Bandelj, V., Codermatz, R., Cossarini, G., Melaku Canu, D., Ravagnan, E. Salon, S., Trevisani, S., 2009. Current state, scales of variability, and trends of biogeochemical properties in the northern Adriatic Sea. J. Geophys. Res. 114, C07S91. http://dx.doi.org/10.1029/2008JC004838.

Stachowitsch, M., 1984. Mass mortality in the gulf of Trieste: the course of community destruction. Mar. Ecol. 5 (3), 243-264.

Stachowitsch, M., 1991. Anoxia in the Northern Adriatic Sea: rapid death, slow recovery. In: Tyson, R.V., Pearson, T.H. (Eds.), Modern and Ancient Continental Shelf Anoxia. Geological Society Special Publication. 58, pp. 119-129.

Steckbauer, A., Duarte, C.M., Carstensen, J., Vaquer-Sunyer, R., Conley, D.J., 2011. Ecosystem impacts of hypoxia: thresholds of hypoxia and pathways to recovery. Environ. Res. Lett. 6, 1-12.

Stefanon, A., Boldrin, A., 1980. The oxygen crisis of the northern Adriatic Sea waters in late fall 1977 and its effects on benthic communities. In: Blanchard, J., Mair, J., Morrison, I. (Eds.), Proceedings of 6th International Science Symposium World Underwater Federation (CMAS). National Environmental Research Council, Edinburgh, pp. 167-175.

Strickland, J.D., Parsons, T.T., 1972. A practical handbook of seawater analysis. Bull. Fish. Res. Board Can. 167, 310.

Supić, N., Orlić, M., 1999. Seasonal and interannual variability of the northern Adriatic surface fluxes. J. Mar. Syst. 20, 205-229.

Supić, N., Orlić, M., Degobbis, D., 2000. The Istrian countercurrent and its year to year variability. Estuar. Coast. Shelf Sci. 51, 385-397.

Supić, N., Orlić, M., Degobbis, D., 2003. Istrian Coastal Countercurrent in the year 1997. Il Nuovo Cimento 26, 117-131.

Supić, N., Kraus, R., Kuzmić, M., Paschini, E., Precali, R., Russo, A., Vilibić, I., 2012. Predictability of northern Adriatic winter conditions. J. Mar. Syst. 90, 42-57.

Tedesco, L., Socal, G., Acri, F., Veneri, D., Vichi, M., 2007. NW Adriatic Sea biogeochemical variability in the last 20 years (1985-2005). Biogeosciences 4, 673-687.

UNEP, 2012. State of the Mediterranean Marine and Coastal Environment 2012 UNEP. Mediterranean Action Plan (MAP), (2012).

UNESCO, 1983. Algorithms for computation of fundamental properties of seawater. UNESCO Technical Papers in Marine Science. 44, p. 53.

Zavatarelli, M., Raicich, F., Bregant, D., Russo, A., Artegiani, A., 1998. Climatological biogeochemical characteristics of the Adriatic sea. J. Mar. Syst 18, 227-263.

Zuschin, M., Stachowitsch, M., 2009. Epifauna-dominated benthic shelf assemblages: lessons from the modern Adriatic Sea. Palaios 24 (4), 211-221. 